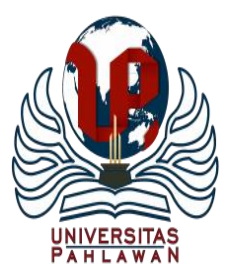

JURNAL BASICEDU

Volume 5 Nomor 3 Tahun 2021 Halaman 1418 - 1426

Research \& Learning in Elementary Education

https://jbasic.org/index.php/basicedu

\title{
Pengembangan Handout Tematik Berbasis Model Inkuiri di Sekolah Dasar
}

\author{
Yulandari $^{1 \bowtie}$, Dea Mustika ${ }^{2}$
}

Pendidikan Guru Sekolah Dasar, Universitas Islam Riau, Indonesia ${ }^{1,2}$

E-mail: yulandari579@gmail.com ${ }^{1}$, deamustika1525@ @mail.com ${ }^{2}$

\begin{abstract}
Abstrak
Penelitian ini bertujuan untuk mengembangkan bahan ajar handout berbasis model inkuiri pada tema 6 subtema 1 untuk kelas V SDN. Penelitian ini merupakan penelitian pengembangan menggunakan model ADDIE yang peneliti batasi sampai tahap implementasi. Instrumen yang digunakan yaitu lembar validasi ahli, angket respon guru, angket respon siswa, wawancara dan dokumentasi. Melibatkan ahli materi, ahli desain, dan ahli bahasa serta menguji kepraktisan handout dengan melakukan uji skala terbatas untuk mendapatkan respon peserta didik dan guru. Hasil validasi oleh ahli materi diperoleh persentase 88,3\%, ahli desain 95,8\%, ahli bahasa $91,2 \%$. Sehingga menunjukkan bahan ajar handout yang dikembangkan sangat valid. Bahan ajar handout yang dikembangkan mendapat tanggapan yang sangat baik dan antusias dari guru dan peserta didik. Hal ini dapat dilihat dari rata-rata respon guru $97 \%$ dan rata-rata respon siswa 96,4\%. Berdasarkan hasil validasi dari para ahli diperoleh produk bahan ajar handout tematik berbasis model inkuiri dengan kategori sangat valid dan sangat praktis.
\end{abstract}

Kata Kunci: Pengembangan, Bahan Ajar, Handout, Tematik, Inkuiri. Tema 6 Subtema 1.

\begin{abstract}
This study aims to develop handout teaching materials based on inquiry models on theme 6 sub-themes 1 for grade V SDN. This research is a development research using the ADDIE model which researchers limit it to the implementation stage. The instruments used were expert validation sheets, teacher response questionnaires, student response questionnaires, interviews and documentation. Involving material experts, design experts, and linguists and testing the practicality of handouts by conducting a limited scale test to get the responses of students and teachers. The results of the validation by material experts obtained a percentage of $88.3 \%$, design experts $95.8 \%$, linguists $91.2 \%$. So that it shows the handout teaching materials developed are very valid. The handout teaching materials developed received very good and enthusiastic responses from teachers and students. This can be seen from the teacher's average response rate of $97 \%$ and the average student response to $96.4 \%$. Based on the validation results from the experts, the thematic handout teaching materials based on the inquiry model were categorized as very valid and very practical.
\end{abstract}

Keywords: Development, Teaching Materials, Handouts, Thematic, Inquiry. Theme 6 Sub-theme 1.

Copyright (c) 2021 Yulandari, Dea Mustika

Corresponding author :

Email : yulandari579@gmail.com

DOI : https://doi.org/10.31004/basicedu.v5i3.935

ISSN 2580-3735 (Media Cetak)

ISSN 2580-1147 (Media Online) 


\section{PENDAHULUAN}

Belajar merupakan proses aktif internal individu, dimana melalui pengalamannya berinteraksi dengan lingkungan menyebabkan terjadinya perubahan tingkah laku yang relatif permanen. Menurut Majid (2014:15), belajar pada hakikatnya merupakan proses perubahan di dalam kepribadian seseorang peserta didik yang berupa kecakapan, sikap, kebiasaan, dan kepandaian. Perubahan ini bersifat permanen dalam tingkah laku yang terjadi sebagai suatu hasil dari latihan atau pengalaman. Pembelajaran merupakan seperangkat tindakan yang dirancang untuk mendukung proses belajar peserta didik. Menurut Undang-Undang Republik Indonesia Nomor 20 tahun 2003 (dalam Pane dan Muhammad, (2017:337), tentang Sistem Pendidikan Nasional, bahwa pembelajaran adalah "proses interaksi pendidik dengan peserta didik dan sumber belajar yang berlangsung dalam suatu lingkungan belajar". Proses pembelajaran selain guru memegang peranan penting dalam proses pembelajaran, ketersediaan bahan ajar juga sangat penting untuk menunjang proses pembelajaran agar terlaksana dengan baik.

Bahan ajar adalah sumber belajar yang sampai saat ini memiliki peranan penting untuk menunjang proses pembelajaran. Bahan ajar pada dasarnya adalah sesuatu yang memuat informasi dan pengetahuan yang dapat dipelajari oleh penggunanya. Menurut Wijayanti, dkk (2015:95), menyatakan bahwa bahan ajar merupakan materi pembelajaran yang disampaikan guru kepada peserta didik, sehingga diperlukan bahan ajaryang mampu mewadahinya. Bahan ajar mempengaruhi keberhasilan peserta didik dalam proses belajar selain peranan seorang guru, maka dari itu perlu dirumuskan bahan ajar yang mampu mendukung terselenggarakannya pendidikan yang baik. Jenis bahan ajar dikelompokkan menjadi empat. menurut Majid (dalam Arsanti, 2018:74) yaitu (1) Bahan cetak antara lain handout, buku, modul, lembar kerja siswa, gambar. (2) Bahan ajar dengar (audio) seperti kaset, radio, dan CD audio. (3) Bahan ajar pandang dengar (audio visual) seperti video CD, film. dan (4) Bahan ajar interaktif seperti CD interaktif. Empat jenis bahan ajar tersebut akan sangat bermanfaat dalam proses pembelajaran jika digunakan secara tepat sesuai dengan tujuan pembelajaran yang akan dicapai.

Penggunaan bahan ajar bermanfaat bagi guru dan siswa. Beberapa manfaat pengembangan bahan ajar bagi guru diuraikan Kemendiknas (dalam Abidin, (2014:264),yaitu: (1) diperoleh bahan ajar yang sesuai dengan tuntutan kurikulum dan sesuai dengan kebutuhan belajar peserta didik. (2) tidak lagi tergantung kepada buku teks. 3) memperkaya pengetahuan karena dikembangkan dengan pengalaman guru dalam menulis bahan ajar. (4) menambah khasanah pengetahuan dan pengalaman guru dalam menulis bahan ajar. (5) membangun komunikasi pembelajaran yang efektif antara guru dengan peserta didik karena peserta didik akan merasa lebih percaya kepada gurunya. (6) menambah angka kredit jika dikumpulkan menjadi buku dan diterbitkan. Sejalan dengan manfaat penyusunan bahan ajar bagi guru, bagi siswa pun penyusunan bahan ajar memiliki beberapa manfaat, yaitu: (1) kegiatan pembelajaran menjadi lebih menarik dan tidak membosankan. (2) kesempatan untuk belajar secara mandiri dan mengurangi ketergantungan terhadap kehadiran guru. (3) mendapatkan kemudahan dalam mempelajari setiap kompetensi yang harus dikuasai.

Bedasarkan hasil wawancara dengan guru kelas V SDN 001 Lubuk Gaung Dumai pada tanggal 10 September 2020, dalam proses pembelajaran guru menyatakan bahan ajar yang biasa digunakan oleh guru dalam proses belajar mengajar yaitu buku dan LKS. Dalam proses pembelajaran belum tersedianya bahan ajar lain sebagai penunjang pembelajaran. Hal ini disebabkan oleh keterbatasan waktu dan minimnya pengetahuan guru dalam membuat bahan ajar lain. Berdasarkan hasil pengamatan yang dilakukan oleh peneliti terhadap bahan ajar yang digunakan oleh guru pada tema 6 subtema 1, terdapat banyak materi yang menuntut peserta didik untuk menghafal semua materi. Adapun hasil analisis yang dilakukan oleh peneliti terhadap buku ajar peserta didik yang pertama yaitu belum terlihat adanya merumuskan hipotesis padahal kegiatan ini sangat penting karena untuk memancing pengetahuan dan pendapat peserta didik terhadap materi yang akan dipelajari. Kedua yaitu belum terlihat adanya menguji hipotesis padahal menguji hipotesis perlu dilakukan untuk mencari tingkat keyakinan dari suatu permasalahan yang akan dipecahkan. Ketiga belum terlihat adanya 
kesimpulan padahal membuat kesimpulan pada akhir pembelajaran harus dilakukan untuk menyamakan persepsi peserta didik.

Hal itu pun berdampak pada proses pembelajaran yang terjadi di kelas dimana buku ajar yang digunakan masih terdapat banyak materi yang mengharuskan siswa menghafal. Sehingga mengakibatkan rendahnya hasil belajar siswa dan tidak memenuhi kriteria ketuntasan minimal (KKM) yang sudah diterapkan sekolah yaitu 76. Karena berdasarkan observasi dengan guru kelas dari 25 orang peserta didik yang tuntas hanya 9 orang siswa dan 16 peserta didik lagi tidak tuntas dalam ulangan harian tematik pada tahun 2019. Berdasarkan permasalahan diatas maka perlu adanya penggunaan bahan ajar yang dapat mempertimbangkan kebutuhan siswa. Bahan ajar alternatif yang dapat dikembangkan oleh guru salah satunya adalah handout untuk pembelajaran tematik sebagai penunjang siswa belajar secara mandiri dan meningkatkan pemahaman siswa terhadap materi yang diberikan guru. Handout tematik perlu dikembangkan agar terciptanya inovasi baru terhadap pembelajaran sertadapat membantu siswa agar lebih mudah memahami materi tematik yang dipelajari karena handout berisi ringkasan materi. Menurut Pribadi dan Dewi (2019:2.9), "handout pada dasarnya adalah artikel atau lembaran yang berisi informasi dan ringkasan materi yang akan dibahas dalam sebuah kegiatan pembelajaran". Kelebihan handout salah satunya yaitu dapat merangsang rasa ingin tahu siswa dan dapat memelihara kekonsistenan penyampaian materi pelajaran dikelas oleh guru sesuai dengan perancangan pengajaran.

Pengembangan bahan ajar handout tematik tema 6 subtema 1 dilakukan karena belum tersedianya handout tematik tema 6 subtema 1 di SDN 001 Lubuk Gaung Dumai, serta handout termasuk bahan ajar cetak, serta materi yang dituangkan ringkas, jelas, padat, serta tatanan bahasa mudah dimengerti oleh siswa. Penggunaan handout sebagai salah satu bahan ajar yang digunakan guru memberikan dampak cukup besar bagi siswa dalam memahami materi yang diberikan oleh guru apalagi jika handout tersebut dibuat oleh guru itu sendiri karena sesuai dengan kondisi siswa di dalam kelas karena handout berisi ringkasan materi-materi yang akan dipelajari oleh siswa. Hal ini sejalan dengan penelitian sebelumnya yang dilakukan oleh Suprayitno dan Nisfi (2020:407), menyatakan bahwa penggunaan bahan ajar handout tematik dikatakan sangat baik dan mendapat respon positif dari siswa dan guru.

Berdasarkan permasalahan diatas maka handout dapat dikembangkan dengan model inkuiri karena belum terdapat adanya merumuskan hipotesis pada buku ajar yang digunakan oleh siswa, padahal kegiatan ini sangat penting untuk memancing pengetahuan dan pendapat peserta didik terhadap materi yang akan dipelajari. Oleh karena itu perlu dikembangkan model inkuiri karena model inkuiri merupakan rangkaian pembelajaran yang melibatkan siswa secara aktif untuk menemukan dan memecahkan suatu permasalahan. Tahapan model inkuiri terdapat langkah pembelajaran yang sesuai dengan permasalahan yang ditemukan. Tujuan utama model inkuiri adalah mengembangkan kemampuan berpikir sehingga model ini selain berorientasi pada hasil belajar, juga berorientasi pada proses belajar. Dengan adanya pengembangan bahan ajar handout berbasis inkuiri ini diharapkan siswa dapat menemukan dan memecahkan suatu permasalahan dalam pembelajaran, dapat membangkitkan motivasi dan minat belajar siswa dalam proses pembelajaran. Serta diharapkan dapat membantu peserta didik dalam memahami materi pelajaran sehingga dapat meningkatkan hasil belajar peserta didik menjadi lebih baik.

\section{METODE}

Penelitian ini menggunakan model penelitian pengembangan. Desain yang digunakan dalam penelitian ini adalah desain model ADDIE. Model ini terdiri atas 5 tahap pengembangan yaitu: (1)Analyze (Analisis) (2)Design (Perancangan), (3)Development (Pengembangan), (4)Implementation (Implementasi), (5)Evaluation (Evaluasi). Dalam penelitian ini peneliti membatasi penerapan model ADDIE sampai tahap implementasi. karena sekolah masih menggunakan sistem daring sehingga fokus pada perancangan dan pengembangan yaitu untuk menghasilkan modul pembelajaran yang valid dan praktis. 
Data penelitian ini diperoleh dari data primer dan data sekunder. Data primer yaitu data yang diambil langsung dari sumber data. Teknik yang dapat digunakan peneliti untuk mengumpulkan data primer adalah wawancara, dokumentasi, angket validasi ahli desain, angket validasi ahli materi, ahli bahasa, angket respon guru dan angket respon siswa kelas V SDN 001 Lubuk Gaung. Data sekunder yaitu data yang dikumpulkan peneliti dari sumber yang telah ada. Pada penelitian ini data sekunder dapat dari buku, jurnal serta skripsi yang berkaitan dengan pengembangan. Sumber data dalam penelitian ini terdiri dari ahli yang memiliki kompeten dalam beberapa bidang yang berkaitan dengan bahan ajar yaitu ahli materi yang berkompeten dalam menguji isi, ahli desain yang berkompeten dalam menguji konstruk, ahli bahasa yang berkompeten dalam menguji bahasa yang ada di dalam handout. Sumber data lainnya pada penelitian ini yaitu angket respon guru dan siswa SDN 001 Lubuk Gaung Dumai. Subjek dalam penelitian ini dilakukan dengan uji skala terbatas yang berjumlah 6 siswa kelas V SDN 001 Lubuk Gaung Dumai. Teknik penelitian ini dilakukan dengan studi pendahuluan yaitu wawancara dan observasi dilanjutkan dengan pelaksanaan dengan menggunakan teknik angket dan dokumentasi. Adapun instrumen yang digunakan yaitu lembar validasi ahli, angket respon guru, angket respon siswa, wawancara dan dokumentasi. Teknik analisis data dilakukan secara analisis deskriptif.

Penelitian ini merupakan penelitian pengembangan, yaitu pengembangan handout tematik berbasis model inkuiri pada kelas V tema 6 subtema 1. Handout berbasis model inkuiri yang dikembangkan telah dilakukan uji validitas oleh ahli materi, ahli desain dan ahli bahasa serta telah diuji coba praktikalitas untuk mendapatkan respon guru dan respon siswa. Sebelum diuji cobakan kepada siswa, handout tematik berbasis model inkuiri sebelumnya telah di validasi oleh ahli materi, ahli desain dan ahli bahasa. Hasil validasi handout pembelajaran oleh ahli materi, ahli desain dan ahli bahasa yang dianalisis menggunakan statistik deskriptif. Data dalam perangkat berupa nilai 1-4. Menurut Akbar (2013:158) dalam analisis tingkat validitas masing-masing ahli secara deskriptif dapat menggunakan rumus sebagai berikut:

$$
V_{a}=\frac{T S e}{T S h} \times 100 \%
$$

Untuk memperoleh kesimpulan melalui analisis deskriptif peneliti menggunakan analisis gabungan dengan rumus sebagai berikut:

$$
\mathrm{V}=\frac{V a 1+V a 2+V a 3}{3}
$$

Keterangan:

$\mathrm{V}=$ Validasi (Gabungan)

Va1 = Validasi Ahli ke-1

Va2 = Validasi Ahli ke-2

Va3 = Validasi Ahli ke-3

TSh = Total skor maksimal yang diharapkan

Tse $\quad=$ Total skor empiris (hasil validasi dari validator)

Hasil validasi masing-masing validator dan hasil analisis validitas gabungan setelah diketahui, tingkat persentasenya dapat dicocokkan atau dikonfirmasikan dengan kriteria validitas sebagai berikut:

Tabel 1. Kriteria Validitas Handout Pembelajaran

\begin{tabular}{|l|c|c|}
\hline No & Kriteria & Tingkat Validitas \\
\hline 1 & $85,01 \%-100,00 \%$ & Sangat valid, atau dapat digunakan \\
\hline 2 & $70,01 \%-85,00 \%$ & $\begin{array}{c}\text { Cukup valid atau dapat digunakan } \\
\text { namun perlu direvisi kecil }\end{array}$ \\
\hline 3 & $50,01 \%-70,00 \%$ & $\begin{array}{c}\text { Kurang valid, disarankan tidak } \\
\text { dipergunakan karena perlu revisi besar }\end{array}$ \\
\hline 4 & $01,00 \%-50,00 \%$ & $\begin{array}{c}\text { Tidak valid, atau tidak boleh } \\
\text { dipergunakan }\end{array}$ \\
\hline
\end{tabular}


Setelah dinyatakan valid dari masing-masing ahli maka sudah dapat diuji praktikalitas dengan handout tersebut diajarkan oleh guru kemudian diminta mengisi angket dari siswa dan guru. Pengujian praktikalitas ini dengan skala terbatas yaitu hanya 6 orang siswa karena melihat kondisi yang masih dalam keadaan pandemi dan pembelajaran masih menggunakan sistem daring.

Teknik analisis praktilitas yang digunakan adalah analisis deskriptif yang mendeskripsikan handout tematik berbasis model inkuiri. Data yang dikumpulkan dari penelitian ini adalah angket respon guru dan siswa terhadap handout yang dikembangkan oleh peneliti. Untuk menghitung setiap angket digunakan rumus modifikasi Riduwan (dalam Hamdunah, 2015:38) yaitu:

$$
\mathrm{P}=\frac{\sum f}{N} \mathrm{x} 100 \%
$$

Keterangan:

$\mathrm{P}=$ Nilai akhir

$f=$ Perolehan skor

$\mathrm{N}=$ Skor maksimum

Hasil praktis dari angket guru dan siswa serta hasil analisis praktikalitas gabungan setelah diketahui, tingkat persentasenya dapat dicocokkan atau dikonfirmasikan dengan kriteria praktikalitas sebagai berikut:

Tabel 2. Kriteria Praktikalitas handout Pembelajaran

\begin{tabular}{|c|c|c|}
\hline No & Nilai $(\%)$ & Tingkat Praktikalitas \\
\hline 1 & $80<\rho \leq 100$ & Sangat praktis \\
\hline 2 & $60<\rho \leq 80$ & Praktis \\
\hline 3 & $40<\rho \leq 60$ & Cukup praktis \\
\hline 4 & $20<\rho \leq 40$ & Kurang praktis \\
\hline 5 & $\rho \leq 20$ & Tidak praktis \\
\hline
\end{tabular}

Penelitian pengembangan ini menghasilkan handout tematik berbasis model inkuiri kelas V SD. Penelitian ini menggunakan model ADDIE. Dalam Penelitian ini peneliti melaksanakan penelitian sampai tahap implementation (implementasi). Hal ini dikarenakan sekolah masih menggunakan sistem daring sehingga fokus pada perancangan dan pengembangan saja. Berikut uraian dari tahapan yang dilakukan peneliti dari model ADDIE tersebut:

Pada tahap penelitian ini diawali dengan melakukan analisis untuk keperluan pengembangan bahan ajar dan menganalisis kelayakan serta syarat-syarat pengembangan. Analisis dilakukan berdasarkan teknik penelitian yaitu studi pendahuluan dan pengumpulan informasi dengan melakukan identifikasi terhadap potensi dan masalah berkaitan dengan bahan ajar dan pembelajaran. Studi pendahuluan ini dilakukan melalui wawancara dan observasi. Setelah mengidentifikasi potensi masalah, maka selanjutnya dilakukan pengumpulan informasi. Pengumpulan referensi-referensi dan sumber belajar yang relevan, pengintegrasian model inkuiri yang juga akan disesuaikan dengan analisis kebutuhan, analisis kurikulum dan analisis materi.

Dalam mengembangkan bahan ajar handout ada tahapan-tahapan untuk menghasilkan handout berbasis model inkiri, diantaranya yaitu:

a. Merancang Rencana Pelaksanaan Pembelajaran (RPP). Pada tahap ini peneliti mengembangkan Rencana Pelaksanaan Pembelajaran (RPP) yang akan digunakan oleh guru dan peserta didik dalam proses pembelajaran. RPP yang dirancang oleh peneliti ini terdiri dari enam RPP karena dalam satu subtema terdiri dari enam pembelajaran.

b. Penentuan Komponen Handout. Untuk merancang handout, peneliti menggunakan word sebagai pengembangan bahan ajar handout. Pada tahapan ini ada tiga tahapan yang harus di rancang yaitu materi, desain, dan bahasa. 
c. Penentuan Isi Handout. Isi handout dibuat sesuai dengan Kompetensi Dasar dan Indikator yang terdapat pada kurikulum 2013. Handout tematik diintegrasikan menggunakan model inkuiri.

Tahap pengembangan produk bertujuan untuk merealisasikan rancangan yang sudah dibuat. Rancangan tersebut dikembangkan dengan langkah-langkah dibawah ini:

a. Penulisan draft

1) Penulisan draft handout disesuaikan dengan komponen/kerangka handout dan kebutuhan peneliti serta memperhatikan spesifikasi sebagai berikut: Bentuk media cetak yang terdiri atas komponen halaman judul, kata pengantar, daftar isi, KD, tujuan pembelajaran, kegiatan belajar, rangkuman materi, tes formatif, kunci jawaban dan daftar pustaka.

2) Di desain dengan menerapkan komponen-komponen model inkuiri. Dan dimasukkan gambar-gambar disesuaikan dengan materi yang telah ditetapkan.

3) Ditampilkan dengan layout (tampilan) sesuai dengan desain tampilan handout yang telah ditentukan pada tahap desain.

b. Memvalidasikan handout kepada ahli materi, media dan bahasa

Handout harus dinyatakan valid dan layak oleh ahli-ahli tersebut sebelum diimplementasikan dalam pembelajaran. Data hasil evaluasi dari ahli materi, ahli desain dan ahli bahasa selanjutnya dianalisis untuk mengetahui tingkat kevalidan handout dan revisi yang perlu dilakukan berdasarkan masukan dan saran dari ahli-ahli tersebut. Handout yang telah disusun dikonsultasikan secara berkala dan kemudian dilanjutkan dengan penilaian oleh tim ahli materi, ahli desain dan ahli bahasa.

Setelah melakukan validasi dengan tiga orang ahli yang terdiri dari 1 orang ahli materi, 1 orang ahli desain dan 1 orang ahli bahasa. Sehingga handout tematik berbasis model inkuiri ini memperoleh rata-rata yang bisa dilihat pada tabel:

Tabel 3. Rata-Rata Nilai Validasi

\begin{tabular}{|c|c|c|c|}
\hline No & Ahli & Nilai Akhir & Kategori \\
\hline 1 & Validator Materi & $88,3 \%$ & Sangat Valid \\
\hline 2 & Validator Desain & $95,8 \%$ & Sangat Valid \\
\hline 3 & Validator Bahasa & $91,2 \%$ & Sangat Valid \\
\hline & Rata-rata & $91,7 \%$ & Sangat Valid \\
\hline
\end{tabular}

Berdasarkan tabel 2 nilai yang diperoleh dari validasi ahli materi memperoleh rata-rata sebesar $86,5 \%$ dengan kategori sangat valid, ahli desain memperoleh rata-rata sebesar 96,2\% dengan kategori sangat valid, ahli bahasa memperoleh rata-rata sebesar 91,6\% dengan kategori sangat valid. Sehingga nilai rata-rata yang diperoleh dari modul matematika berbasis etnomatematika sebesar 91,5\% dengan kategori sangat valid.

Pada tahap ini handout yang dikembangkan di uji coba kepada siswa. Setelah handout dinyatakan valid dan layak, maka bahan ajar berupa handout dicetak sebanyak jumlah yang dibutuhkan dan kemudian diimplementasikan dalam uji skala terbatas. Pada tahap uji skala terbatas ini peneliti menguji praktikalitas kepada guru dan peserta didik. ada uji coba terbatas ini diambil sampel 6 orang siswa.

Diketahui melalui angket respon yang diisi oleh guru dan siswa terhadap handout, dengan hasil respon yang diperoleh dari guru dan siswa sebagai berikut: 
1424 Pengembangan Handout Tematik Berbasis Model Inkuiri di Sekolah Dasar - Yulandari, Dea Mustika DOI: https://doi.org/10.31004/basicedu.v5i3.935

Tabel 4. Hasil Respon Guru Kelas IV SDN 001 Lubuk Gaung Dumai

\begin{tabular}{|c|c|c|c|}
\hline No & Aspek Penilaian & Ibu Merpat & Kategori \\
\hline 1 & Isi handout & $100 \%$ & Sangat Praktis \\
\hline 2 & Sajian dalam handout & $92,5 \%$ & Sangat Praktis \\
\hline 3 & Manfaat bahan ajar bafi guru & $96 \%$ & Sangat Praktis \\
\hline 4 & Peluang implementasi handout & $100 \%$ & Sangat Praktis \\
\hline & Rata-rata & $97 \%$ & Sangat Praktis \\
\hline
\end{tabular}

Berdasarkan tabel 4 respon yang diberikan guru kelas $\mathrm{V}$ memperoleh rata-rata persentase sebesar 97\% dengan kategori bahwa handout tematik berbasis model inkuiri sangat praktis.

Selanjutnya dilakukan tahapan uji coba produk yakni uji coba skala terbatas yang terdiri 6 orang siswa, sehingga memperoleh hasil:

Tabel 5. Hasil Respon Siswa Kelas V SDN 001 Lubuk Gaung Dumai

\begin{tabular}{|c|c|c|c|c|c|}
\hline No & Nama & Jumlah & Skor Max & Persentase & Kriteria \\
\hline 1 & EP & 13 & 14 & $92,8 \%$ & Sangat Praktis \\
\hline 2 & JF & 12 & 14 & $85,7 \%$ & Sangat Praktis \\
\hline 3 & NB & 14 & 14 & $100 \%$ & Sangat Praktis \\
\hline 4 & MM & 14 & 14 & $100 \%$ & Sangat Praktis \\
\hline 5 & SA & 14 & 14 & $100 \%$ & Sangat Praktis \\
\hline 6 & ZI & 14 & 14 & $100 \%$ & Sangat Praktis \\
\hline \multicolumn{2}{|r|}{ Jumlah Skor } & 81 & 84 & $100 \%$ & Sangat Praktis \\
\hline
\end{tabular}

Berdasarkan tabel 5 hasil respon dari 6 orang siswa kelas V SDN 001 Lubuk Gaung diperoleh rata-rata persentase penilaian sebesar $96,4 \%$ dengan kriteria sangat praktis.

Berdasarkan proses megembangkan handout berbasis model inkuiri terdapat tiga proses yang peneliti lalui yaitu: Menemukan suatu permasalahan melalui wawancara dan observasi dengan guru kelas V SDN 001 Lubuk Gaung Dumai, setelah menemukan masalah peneliti menganalisis kurikulum yang digunakan sekolah guna untuk menentukan Kompetensi Dasar dan Indikator pada terdapat dalam kurikulum 2013 materi tema 6 (suhu dan perpidahannya) subtema 1 (suhu dan kalor) yang nantinya diintegrasikan dengan model inkuiri, Selanjutnya membuat handout tematik berbasis model inkuiri. Validitas handout tematik berbasis model inkuiri dan proses praktikalitas handout tenatik berbasis model inkuiri. Sehingga memperoleh rata-rata dari para ahli yaitu 1) handout tematik berbasis model inkuiri yang divalidasi oleh ahli materi memperoleh ratarata 88,3\% dengan kategori sangat valid. 2) handout tematik berbasis model inkuiri yang divalidasi oleh ahli desain memperoleh rata-rata 95,8\% dengan kategori sangat valid. 3) handout tematik berbasis model inkuiri yang divalidasi oleh ahli bahasa memperoleh rata-rata 91,2\% dengan kategori sangat valid. Jadi nilai rata-rata yang diperoleh dari validasi ini yaitu 91,7\% dengan kategori sangat valid. Setelah dilakukan validasi dengan ahli materi, ahli desain dan ahli bahasa selanjutnya penilaian dilakukan untuk mendapat respon dari siswa dan guru kelas V SDN 001 Lubuk Gaung Dumai. Guru diminta untuk mengajarkan tema 6 subtema 1 menggunakan handout yang dikembangkan Peneliti pada saat proses pembelajaran, dan mengisi angket respon untuk menilai handout sehingga memperoleh rata-rata sebesar 97\% dengan kategori sangat praktis. Pada tahapan implementasi dilakukan dengan enam orang siswa dari kelas V SDN 001 Lubuk Gaung Dumai. Respon yang diberikan oleh siswa memperoleh rata-rata 96,4\% dengan kategori sangat praktis. 


\section{KESIMPULAN}

Berdasarkan hasil penelitian yang dilakukan, dapat disimpulkan bahwa: Proses pengembangan handout tematik berbasis model inkuiri melalu dua tahapan yaitu penulisan draf handout, dan memvalidasikan handout tematik berbasis model inkuiri kepada ahli materi, ahli desain serta ahli bahasa. Handout Tematik berbasis model inkuiri pada tema 6 (panas dan perpindahannya) subtema 1 (suhu dan kalor) yang dikembangkan sangat valid berdasarkan kriteria validasi menurut penliaian validator. Berdasarkan hasil validasi ahli materi diperoleh persentasi sebesar $88,3 \%$, ahli desain diperoleh persentasi sebesar $95,8 \%$, dan ahli bahasa diperoleh persentasi sebesar 91,2\%. Handout tematik berbasis model inkuiri mendapat tanggapan sangat praktis dari guru dan siswa. Berdasarkan angket respon guru diperoleh persentasi sebesar $97 \%$ dan angket respon siswa medapat persentasi sebesar $96,4 \%$. Berdasarkan hasil penilaian oleh validator ahli materi, ahli bahasa, ahli desain serta angket repon guru dan siswa maka handout tematik berbasis mosel inkuiri pada tema 6 (panas dan perpindahannya) subtema 1 (suhu dan kalor) memenuhi kriteria sangat valid dan sangat praktis.

\section{UCAPAN TERIMA KASIH}

Peneliti mengucapkan terima kasih terhadap orang tua, keluarga, dosen pembimbing, sahabat serta rekan-rekan yang telah terlibat dalam penyelesaian penelitian ini, yang telah membantu secara langsung maupun tidak langsung sehingga penelitian ini dapat diselesaikan dan dilaporkan secara tertulis.

\section{DAFTAR PUSTAKA}

Abidin, Yunus. 2014. Desain Sistem Pembelajaran dalam Konteks Kurikulum 2013. Bandung: PT. Refika Aditama. Halaman 263-265.

Akbar, Sa'dun. 2013. Instrumen Perangkat Pembelajaran. Bandung: PT Remaja Rosdakarya

Israwani. (2015). Penggunaan Model Pembelajaran Inkuiri Pada Materi Operasi Hitung Bilangan Di Kelas I Sd Negeri 53 Banda Aceh,Jurnal Peluang, Vol 3 No 2, (Online), Diakses pada tanggal 06 Desember 2020.

Karitas Diana dan Fransiska. (2017). Buku Tematik Terpadu Kurikulum 2013. Jakarta: Kementerian Pendidikan dan Kebudayaan.

Kurniasih, Imas. (2015). Ragam Pengembangan Model Pembelajaran Untuk Peningkatan Profesionalitas Guru. Yogyakarta: Kata Pena.

Kurniawan, Deni. (2014). Pembelajaran Tematik Terpadu Tematik (Teori, Praktik, dan Penilaian). Bandung: Alfabeta.

Kristianto, Yusuf. (2019). Penerapan Model Pembelajaran Inkuiri Untuk Meningkatkan Berpikir Kritis Dan Hasil Belajar Siswa Dalam Pembelajaran Ipa Kelas IV SD, Jurnal mitra pendidikan Vol 03 No 11, (Online), Diakses pada tanggal 01 Desember 2020.

Majid, Abdul. (2014). Pembelajaran Tematik Terpadu. Bandung: PT Remaja Rosdakarya.

Muhsam Julhidayat. (2020). Pengembangan Lembar Kerja Siswa (Lks) Berbasis Model Inkuiri Terintegrasi Life Skills Pada Siswa Kelas IV SD Negeri Oeba 3 Kupang,Jurnal Pendidikan Dasar Flobamorata Vol 1 No.1, (Online), Diakses pada tanggal 03 Desember 2020.

Ningtyas, Retno, dkk. (2014). Pengembangan Handout Pembelajaran Tematik Untuk Siswa Sekolah Dasar Kelas III, Jurnal Scholaria Vol. 4 No.3, (Online), Dakses pada 07 November 2020.

Prastowo, Andi. (2014). Pengembangan Bahan Ajar Tematik. Jakarta: Kencana. 
1426 Pengembangan Handout Tematik Berbasis Model Inkuiri di Sekolah Dasar - Yulandari, Dea Mustika DOI: https://doi.org/10.31004/basicedu.v5i3.935

Purwanto, Kelik dan Aulia Rahmawati. (2017). Pengembangan Handout Untuk Siswa Kelas V SDN 14 Koto Baru Pada Materi Bermain Drama,Jurnal Tarbiyah, Vol Xxiv, No.1, (Online), Diakses pada tanggal 07 November 2020.

Rakhmadina, Nifsi Laili dan Suprayitno. (2020). Pengembangan Bahan Ajar Handout Materi Karya Seni Kolase Berbasis Bahan Alam Untuk Kelas IV SD, Jurnal PGSD, Vol 08 No.02, (Online), Diakses pada tanggal 15 November 2020.

Riduwan. (2016). Dasar-Dasar Statistika. Bandung: Alfabeta

Shoimin, Aris. (2014). 68 Model Pembelajaran Inovatif dalam Kurikulum 2013. Yogyakarta: Ar-ruzz Media.

Sugiyono. (2014). Metode Penelitian Pendidikan Pendekatan Kuantitatif, Kualitatif, dan R\&D. Bandung: Alfabeta. 